\title{
Mobility and Selection in Scottish University Medical Education, 1858-1886
}

\author{
JAMES BRADLEY, ANNE CROWTHER, \\ MARGUERITE DUPREE*
}

\section{Introduction: Metropolitan and Peripheral Views of Medical Education}

In 1871 , the Scotsman reported a speech by the Right Hon. Robert Lowe, educational reformer and Member of Parliament for the University of London. The gist of the speech, as delivered to "the annual soirée of the Mechanics' Institute of Halifax", was that

there are many young men who go up to Edinburgh to be educated for the medical profession. The examination in the Edinburgh College may be easily passed, but I am glad to testify that numbers of these prefer to come and pass the more severe examination imposed upon them by the University of London. ${ }^{1}$

These observations caused a flurry in the University of Edinburgh, which had previously conferred an honorary degree on Lowe; but it revealed a view apparently widespread in English medical institutions. Although the Medical Act of 1858 had laid the ground for the transformation of the medical profession in Britain, particularly through its impact on medical education, it seemed that there was still a hierarchy of respect among the institutions responsible for medical education and that, in particular, the major Scottish universities were failing to provide the highest standards of examination for prospective entrants to the profession. This was in spite of the efforts to centralize the system of medical education. The creation of the General Medical Council (GMC) allowed the medical profession to define a "legitimate" practitioner through the Medical Register and a number of other procedures. The GMC advised on the length of the medical curriculum and the subjects to be studied. It hoped to tighten recruitment to the profession by ensuring that all medical students passed a preliminary examination to test knowledge of the

*Dr James Bradley, Wellcome Unit for the History of Medicine, University of Glasgow, 5 University

Gardens, Glasgow G12 8QQ.

Professor M Anne Crowther, Department of Economic and Social History, University of Glasgow, 4 University Gardens, Glasgow G12 8QQ. Dr Marguerite Dupree, Wellcome Unit for the History of Medicine, University of Glasgow, 5 University Gardens, Glasgow G12 8QQ.

We are grateful to the Wellcome Trust for its support of the research on which this paper is based (Wellcome Trust Project Grant No.

036579/z/92/z/DEA). We also appreciate the assistance of Michael Moss, the Glasgow University
Archivist, and his staff who generously made available both the original source and the machinereadable dataset of the Glasgow University Matriculation Albums 1859-1888; Jo Currie and the staff of the Special Collections Department of Edinburgh University Library; and Alison Spurway and Jean Allan of the Faculty of Medicine, University of Glasgow for supplying us with information on completion rates of recent medical students.

\footnotetext{
1 Douglas MacLagan, 'Address to the Edinburgh medical graduates, 1st August 1872' Edinburgh med. J., 1872-3, 18: 313-24, pp. 318-19.
} 


\section{James Bradley, Anne Crowther, Marguerite Dupree}

humanities. It established in 1866 the List of medical students registered during the year to check that students had passed the necessary preliminary examinations and studied medicine for at least four years before commencing practice. ${ }^{2}$ Through the power of visitation it assessed the standards of professional examination at each of the bodies offering registerable medical qualifications.

If there was an intention of the Act to raise the income and status of the medical profession by removing the spectre of "overstocking", it appears to have been successful. Between 1861 and 1881 the ratio of practitioners to population decreased from 1:1392 to $1: 1721 .^{3}$ This reduction has indeed been interpreted as part of a strategy of occupational closure by which the medical profession restricted the supply of practitioners. ${ }^{4}$ Other components of occupational closure associated with the Act included progress towards greater standardization of medical education through interaction between the GMC and the educational institutions and the reinforcement of a professional identity in the "shared experiences" of medical students "living and working together" in their chosen places of study. 5

The arguments about occupational closure link the social status of the medical profession to educational reform, and have been thoroughly explored in a number of standard histories. ${ }^{6}$ This essay concentrates on the system of medical education in the later nineteenth century, and in particular on the profession's methods of selection to its ranks. ${ }^{7}$ Today the Darwinian struggle for entry to the profession occurs mainly in intense competition for a place at medical school; but for some eighty years after the Medical Act, the principle was to cull after study had begun. The Act tried to develop a more homogeneous profession, but there was far more prestige in attending a London medical school than a provincial college. The GMC hardly pretended that one institution was as good as another, but a major concern was to prevent the "inferior" schools from offering "easy" qualifications and discrediting the profession.

\footnotetext{
2 From 1866 until 1939 the GMC published annually the List of medical students registered during the year (which by 1909 had become the Medical students' register. List of medical students registered during the year) containing a list of all those who registered for the first time as students in medicine during that year. A student registered by obtaining from a recognized place of medical education an application form which required the signature of an official of the medical school where the student began his studies. The student sent the completed form together with a certificate indicating that he had passed the Preliminary Examination to the GMC's branch registrar for the division of the UK in which he resided within 15 days of beginning his medical studies, and received a certificate in return. The branch registrars sent their registers annually to the registrar of the GMC who prepared and printed the alphabetical list. In 1873, for example, the GMC printed 250 copies of the 'Students' register'. It should not be confused with the Medical Register which includes all qualified practitioners and was published in far greater numbers (3,000 in 1873). Minutes of the General
}

Medical Council, vol. xi, 1874, p. 94. Parliamentary Papers 1879 (320), pp. 390-2, 'Special report of the Select Committee on the Medical Act (1858) Amendment (No. 3) Bill [Lords] ..., Appendix No. 11.

3 Ivan Waddington, The medical profession in the industrial revolution, Dublin, Gill \& Macmillan, 1984 , p. 149.

4 Ibid., pp. 138-9; N Parry and J Parry, The rise of the medical profession. A study of collective social mobility, London, Croom Helm, 1976, p. 131.

$5 \mathrm{M}$ Jeanne Peterson, The medical profession in mid-Victorian London, Berkeley, California and London, University of California Press, 1978, ch. 2, pp. 40-89, esp. pp. 88-9.

6 For example: Parry and Parry, op. cit., note 4 above; Peterson, op. cit., note 5 above; Waddington, op. cit., note 3 above.

7 These internal hierarchies are discussed in, e.g., Peterson, op. cit., note 5 above; Anne Digby, Making a medical living: doctors and patients in the English market for medicine 1720-1911, Cambridge University Press, 1994. 


\section{Scottish University Medical Education, 1858-1886}

At the time of the Medical Act, London was once again the centre of prestige in medical education. Edinburgh made a powerful claim in the eighteenth century, but its nepotistic and inflexible medical faculty was held in less regard by the early nineteenth century. ${ }^{8}$ It was, however, difficult to distinguish between criticism of Scottish education aimed at real weaknesses (such as the "sale" of medical degrees in St Andrews and Aberdeen), and the territorial needs of the London corporations to keep the battalions of Scottish medical men out of London. ${ }^{9}$ Anti-Scots prejudice was not new, and certain features in Scottish medical education reinforced it after 1858.

In particular, the evidence put before the Select Committee set up in 1879 to consider amendments to the Medical Act revealed English anxiety about the standards of a Scottish medical qualification. Such anxiety was used to support proposals for a "single portal" of entry to the profession through unified regulations and a consolidated examining authority. ${ }^{10}$ The Scottish universities and, by 1879 , the medical corporations strongly objected. The universities feared they would become mere "crammers" for national examinations and the quality of their medical education would suffer if they were deprived of their power to judge their own students and lost the teachers' freedom of action. ${ }^{11}$ The Scottish institutions saw themselves as defending educational standards, but were constantly accused of offering inferior qualifications. Question after question from the English-based Select Committee demanded to know whether it was possible for students who had failed their examinations elsewhere to gain a Scottish qualification after a brief period of study at a Scottish university, and passing less than rigorous examinations at these universities or Scottish medical corporations. ${ }^{12}$ Such questions assumed a mobile student body of the kind usually associated with the period before the Medical Act. Student mobility was related, at least in the minds of the English medical elite (and particularly Henry Acland, the President of the GMC), to low standards and easy entry to the profession. The interrogation left at least two Scottish members of the GMC almost apoplectic with indignation. William Tennant Gairdner, Regius Professor of the Practice of Medicine at Glasgow, was highly affronted by Acland's ignorance of Scottish

${ }^{8}$ David Hamilton, The healers. A history of medicine in Scotland, Edinburgh, Canongate, 1981, pp. 150-1; Lisa Rosner, Medical education in the Age of Improvement, Edinburgh University Press, 1991, pp. 178-84; Christopher Lawrence, 'The Edinburgh Medical School and the end of the "Old Thing" 1790-1830', Hist. Univ., 1988, 7: 259-86; Charles Newman, The evolution of medical education in the nineteenth century, London, Oxford University Press, 1957, p. 229; Stephen Jacyna, Philosophic Whigs: medicine, science and citizenship in Edinburgh, 1789-1848, London, Routledge, 1994, pp. 80-1; Vivian Nutton and Roy Porter (eds), The history of medical education in Britain, Amsterdam and Atlanta, Rodopi, 1995.

9 Hamilton, op. cit., note 8 above, pp. 163-7. The respectability of these degrees has its defenders: see e.g., Rosner, op. cit., note 8 above, pp. 168-9 and Kenneth Collins, Go and learn: the international story of Jews and medicine in Scotland, Aberdeen University Press, 1988, pp. 24-5.
10 Newman, op. cit., note 8 above, pp. 231-9, gives an account of the proposals for a "single portal" originating with Sir John Simon in 1869, and their fate in the succession of Bills in the $1870 \mathrm{~s}$, the Scottish opposition to them, the Select Committee of 1879, and the Royal Commission of 1882.

11 Ibid., pp. 235, 237-8. Newman suggests that the different structure of medical education in England where medical schools had grown up in relation to hospitals and in Scotland where medical education was almost entirely in the hands of the universities, was a factor behind the controversy.

12 Parliamentary Papers 1880 (121), Qs. 296-7, 314, 'Special report of the Select Committee on the Medical Act (1858) Amendment (No. 3) Bill [Lords] ...'; Parliamentary Papers 1879 (320), Qs. 4026, 4028, 4035, 'Special report of the Select Committee on the Medical Act (1858) Amendment (No. 3) Bill [Lords] .... 


\section{James Bradley, Anne Crowther, Marguerite Dupree}

qualifications ("I thought it was not too much to presume that the President of the Medical Council knew as much as that"), while Andrew Wood, from the Royal College of Surgeons in Edinburgh (RCSE), confronted by the allegation that failed Irish students always headed for Scotland, retorted that his "Scottish blood was up". ${ }^{13}$

Histories of medical education for the later nineteenth century have a certain Metropolitan bias, if not quite such a pronounced one as the GMC. ${ }^{14}$ This is understandable given the nature of much of the evidence, based on Parliamentary material and the GMC's own records. Newman's standard work, for example, has relatively little to say about any Scottish institutions outside the University of Edinburgh. ${ }^{15}$ The arguments which follow support the premise that a degree of student mobility remained a feature of medical education long after the Act, but not the contemporary inference that mobility encouraged medical schools to compete for fees by offering easy examinations.

Part of the contemporary anxiety about the quality of Scottish medical education was probably due to the large size of the two dominant Scottish medical schools. Between 1871 and 1880, 13 per cent of all new medical students in the United Kingdom registered at Edinburgh and 8 per cent at Glasgow. The London medical schools and the English provinces admitted 28 per cent and 20 per cent respectively. Edinburgh University received by far the largest number of medical students, 207 per year on average, of any single medical school, while Glasgow was in second position with 121 . Of the individual London schools only the average intake at St Bartholomew's (84) approached this size. ${ }^{16}$ Anti-Scottish prejudice persisted in spite of (or perhaps because of) the fact that the alumni of Glasgow and Edinburgh were prominent in medical elites throughout Great Britain, the Empire and beyond. Even London was permeable, with graduates of the Scottish Universities constituting 38 per cent of the Fellows of the Royal College of Physicians in the period $1850-89 .{ }^{17}$ The evidence to the Select Committee shows considerable confusion between the licences granted by the Scottish corporations and the degree regulations of Edinburgh, Glasgow and Aberdeen universities, and the suspicion attaching to the first may well have spread to the second.

The basis for the following argument is a collective biography of two cohorts, each of approximately 1,000 students, who began their studies at the Universities of Edinburgh and Glasgow in the years centring on $1871 .^{18}$ It has not been possible to provide a full

13 Parliamentary Papers 1880 (121), Q. 314, op. cit., note 12 above; Parliamentary Papers 1879 (320), Q. 4028, op. cit., note 12 above.

14 A number of historians should be exempted from this, including: D Dow and M Moss, 'The medical curriculum at Glasgow in the early nineteenth century', Hist. Univ., 1983, 3: 227-57; Carolyn Pennington, The modernisation of medical teaching at Aberdeen in the nineteenth century,

Aberdeen University Press, 1994.

15 Newman, op. cit., note 8 above.

16 Report of the Statistical Committee of the General Medical Council, London, Spottiswoode \& Co., 1885, pp. 26-7.

17 Peterson, op. cit., note 5 above, p. 50.

18 We use the universities' matriculation records as the basis for the cohorts; we link the information in the matriculation records with information about these individuals derived from other sources, such as the lists of graduates in the universities' Calendars, the Medical Register, the Medical Directory, and obituaries. All Scottish students "matriculated" every year at the beginning of the first term, by signing the university's register or filling in a form, and paying a fee. The Glasgow University cohort includes 974 students who first matriculated in the Medical Faculty between $1866 / 7$ and 1874/5; the Edinburgh University cohort includes 1,025 students who first matriculated in the Medical Faculty between 1868/9 and $1873 / 4$. For information on the method used to identify and select the individuals in the cohorts see: James Bradley and Marguerite Dupree, 'Interpreting datasets: the experience of third-party use of a machine-readable source', History and Computing, 
comparison of our cohorts with a similar group in the period immediately preceding the Medical Act: hence the effects of the Act are not the main concern here. Fortunately, however, there is already a rigorous study of late-eighteenth- and early-nineteenth-century Edinburgh students in Lisa Rosner's Medical education in the Age of Improvement. Rosner's methodology allows comparison with the present study.

Although the Medical Act imposed greater formality on medical education, the generation of students affected by it were still far removed from the modern British system of medical education which is characterized by selectivity at entrance, relative immobility during study, and a high level of successful completion. Between 1981 and 1988, 90 per cent of students enrolling in Medicine at Glasgow University completed the Glasgow MB, $\mathrm{ChB} .{ }^{19}$ Twenty years after the passing of the 1858 Medical Act the pattern of medical education in Scottish universities still resembled Rosner's description of late-eighteenthand early-nineteenth-century Edinburgh: little selectivity (except on financial grounds); medical classes attended by auditors who did not obtain a formal medical qualification; and qualifications available through a highly flexible system, both in terms of its components and the place and type of qualification. ${ }^{20}$ The sections which follow examine two of the main characteristics of this system: student mobility and high levels of noncompletion. To understand the dimensions of mobility it is necessary to examine university regulations, the type of qualifications gained, and the time taken to obtain them.

\section{Medical Education and Student Mobility}

\section{(i) Preconditions for Mobility: the Medical Curricula of Scottish Universities}

After 1858, GMC regulations required students entering medical school to take a preliminary examination in the humanities or demonstrate exemption through previous educational attainment. ${ }^{21}$ Liberal learning would support the profession's claim to social status, and while it did not test aptitude for medical study, the preliminary examination ensured a minimum of education. ${ }^{22}$ The creation of the register of students in 1866 formalized this system, ${ }^{23}$ for thereafter students could take professional examinations only

1993, 5: 169-78; Marguerite Dupree, James Bradley and Anne Crowther, 'Micros and medical students: sources and methods for exploring the educational careers and completion rates of Scottish medical students in the late nineteenth and early twentieth centuries', in Peter Denley (ed.), Computing techniques and the history of universities, Gottingen, Max Planck Institute, forthcoming.

19 We would like to thank Jean Allan of the Faculty of Medicine, University of Glasgow, for supplying us with this data.

20 Rosner, op. cit., note 8 above, p. 62.

21 The requirements were published in Ordinances printed in the relevant University calendars. See, for example, The Glasgow University calendar for the year 1868-69, Glasgow, James Maclehose, 1868, p. 68; The Edinburgh University calendar 1875-76, Edinburgh, James Thin, 1875, p. 147. The full set of
GMC recommendations can be found in Recommendations and opinions of the General Medical Council on the subjects of preliminary examination, of registration of medical students, and of professional education and examination, London, General Medical Council, 1868, pp. 2-6.

22 Parry and Parry, op. cit., note 4 above, pp. 131-2. For a clear statement of the concern for the status of the profession and its improvement through the improvement of the "general culture" of medical men by means of the preliminary examination, see Allen Thomson, 'Opening address to medical students, University of Glasgow, October 29, 1867', pp. 16-18, Glasgow University Library Special Collections, 2325/MS Gen. 1476, Box 9.

${ }^{23}$ See List of medical students registered during the year 1866, London, General Medical Council, 1867, pp. iii-v. 


\section{James Bradley, Anne Crowther, Marguerite Dupree}

if they were registered. Four years had to elapse between the date of registration and medical qualification; and students under 21 could not qualify. ${ }^{24}$ Medical education was founded on a four-year course, although several institutions, including Glasgow and Edinburgh, believed that this was too short. ${ }^{25}$ The Edinburgh Medical Faculty encouraged students to begin their studies in May rather than October, adding an extra summer session to the four-year course. In contrast, "although four years are in all cases required to elapse before the termination of medical study, it appears that only three years' attendance at a medical school is required by the surgical corporations, while the universities define medical study as attendance at a medical school". 26

From 1858, the Scottish universities were regulated not only by the Medical Act, but by ordinances drawn up by the Commissioners appointed under the Universities (Scotland) Act 1858. The Commissioners' ordinances determined the structure of medical education, and created a fairly unified system. ${ }^{27}$ Attendance requirements at systematic lectures, demonstrations and practical studies were "in all material respects the same" at Edinburgh, Glasgow and Aberdeen. ${ }^{28}$ The recommended path to qualification differed slightly between institutions, with minor variations in the subjects taken at each professional examination. ${ }^{29}$ But students were not constrained by the recommendations, and could take courses in any order: furthermore, one of the most significant ordinances permitted them to qualify at a university after having spent only one of their four years of study there. They could spend a year at another university entitled to award the degree of Doctor of Medicine (MD), and were allowed to take up to four courses of lectures from teachers of medicine in the London hospital schools, the College of Surgeons in Dublin, or extra-mural schools in Edinburgh or Glasgow. ${ }^{30}$ The regulations allowed a modular form of education permitting considerable mobility, and students could study for a short period at several institutions. In his address at the opening of the medical year at Glasgow University in October 1867, Professor Allen Thomson made certain that students knew "that however convenient and agreeable it may be for you to obtain your degree or license

\footnotetext{
24 It took until at least 1870 before the system ran effectively. Furthermore, evidence gained from the 'Final examination schedules of the University of Edinburgh 1880' (available in the University of Edinburgh Library Special Collections) indicates that a few individuals who failed component papers of the preliminary examination were allowed to commence their medical study. The minimum period between registration for medical study and qualification was $\mathbf{4 5}$ months. Parliamentary Papers 1879 (320), p. 392, op. cit., note 2 above.

25 Parliamentary Papers 1879 (320), pp. 366-87, op. cit., note 2 above, Paper 3.

26 Ibid., pp. 375, 376, 378.

27 Ordinances Nos. 5 and 8 for the University of Edinburgh, No. 15 for the University of Glasgow, No. 16 for the University of Aberdeen, and Ordinance No. 19 for the University of St Andrews regulated the degrees in Medicine; for the Ordinances and the Commissioners' explanation of the nature and effect of these Ordinances which they
}

issued see: Scottish Universities Commission, General report of the Commissioners Under the Universities (Scotland) Act, 1858, Edinburgh, HMSO, 1863, esp. pp. xxxii-v, 4-5, 15-16, 24-6, 221-31. See also, Pennington, op. cit., note 14 above, p. 13.

28 Scottish Universities Commission, op. cit., note 27 above, p. xxxii; Glasgow University calendar for 1875-76, Glasgow, James Maclehose, 1875, pp. 92-3; Edinburgh University calendar 1875-76, op. cit., note 21 above, pp. 148-9; Pennington, op. cit., note 14 above, pp. 13-14.

29 Pennington, op. cit., note 14 above, pp. 17-18, describes the antipathy that existed towards the course of education at Aberdeen, where the order of examination was felt to be arbitrary and the inclusion of Botany nonsensical.

${ }^{30}$ Glasgow University calendar for 1875-76, op. cit., note 28 above, p. 91 ; Edinburgh University calendar 1875-76, op. cit., note 21 above, p. 150; Pennington, op. cit., note 14 above, p. 17. 


\section{Scottish University Medical Education, 1858-1886}

from the University in which your education has been conducted, it is by no means necessary that you should do so. For, while you may pursue your studies for a part or the whole of your course in this University, you are still free to apply for a diploma or qualification at any of the other licensing boards". ${ }^{31}$ Nevertheless, as will be seen, attachment to one institution was the norm.

\section{(ii) Educational Mobility: Choice and Diversity}

The examination schedules of Edinburgh University provide illustrations of mobility. ${ }^{32}$ William Frederick Bassett, from Australia, enrolled at University College London in 1876, but moved to Edinburgh after one year for the remainder of his education. George Frederick Cooke studied medicine at Guy's Hospital in 1871-2, before matriculating at Edinburgh for the Winter Session of 1872. He stayed at Edinburgh until 1875, and passed his first professional examination. He returned to Guy's where he remained until 1880. During that time he took his second professional examination at Edinburgh in 1878 and passed the diplomas for the Royal College of Surgeons England (MRCS Eng) and Apothecaries Hall (LSA) in 1879. Finally, he graduated with an MB, CM from Edinburgh in 1880. Bassett was part of 27 per cent (one of 277) of Edinburgh matriculands who had studied medicine elsewhere before entering the University.

Yet the larger proportion of students were stable. Gairdner told the Royal Commission on the Medical Acts in $\mathbf{1 8 8 2}$ that "the great majority of the candidates [for graduation] receive their whole medical education in this university". ${ }^{33}$ Gairdner's observation was true of those who gained qualifications. The progress of the Edinburgh and Glasgow cohorts appears in Table 1 which gives details of the primary qualifications obtained by the students in the cohorts.

The following figures (condensed from Table 1) reveal that 70 per cent of Edinburgh matriculands and 68 per cent of Glasgow matriculands who achieved a medical qualification had done so through a university degree from the institution where they matriculated, ${ }^{34}$ but in each case this was less than half the original cohort.

31 Thomson, op. cit., note 22 above, pp. 9-10.

32 'Final examination schedules of the University of Edinburgh', op. cit., note 24 above. The following examples are drawn from the examination schedules for 1880 .

33 Parliamentary Papers 1882 [C.3259-I], p. 233, 'Report of the Royal Commissioners appointed to inquire into the Medical Acts ..... For an account of the experience at Edinburgh of such a student in our cohort see: Alsima [George Skelton Stephenson], Reminiscences of a student's life at Edinburgh in the seventies, Edinburgh, Oliver and Boyd, 1918.

34 Further evidence from the Select Committee of 1879 showed that of the students who graduated during the three years $1876-8,88$ per cent at Glasgow University and 81 per cent at Edinburgh took their whole medical course at these universities. Although some of these students took additional lecture courses elsewhere, this is the most stable group within the student body. Parliamentary Papers 1880 (121), pp. 75-9, op. cit., note 12 above, Appendix No. 4. These figures are likely to be overestimates, as even those qualifying for degrees who appeared to take their entire medical course at one university may have spent time studying at extra-mural medical schools which did not qualify for the degree, or attending at hospitals where no qualifying classes were taken; similarly when they repeated classes at university which they had previously taken elsewhere, they entered in the schedules on which the returns were based only those taken at the university. 


\section{James Bradley, Anne Crowther, Marguerite Dupree}

Table 1

Percentage of Medical Students Achieving Qualifications and Types of Qualifications: Cohorts of Students Matriculating in the Medical Faculty at Edinburgh University in the 1820s, Edinburgh University $c 1871$, and Glasgow University $c 1871^{*}$

\begin{tabular}{|c|c|c|}
\hline $\begin{array}{l}\text { Edinburgh Univ. } \\
1820 \mathrm{~s}\end{array}$ & $\begin{array}{c}\text { Edinburgh Univ. } \\
c 1871\end{array}$ & $\begin{array}{c}\text { Glasgow Univ. } \\
c 1871\end{array}$ \\
\hline$\%$ & (n) $\%$ & (n) $\quad \%$ \\
\hline
\end{tabular}

\begin{tabular}{|c|c|c|c|c|c|c|}
\hline \multicolumn{7}{|l|}{$\begin{array}{l}\text { Univ. Degree from the same } \\
\text { Univ. only }\end{array}$} \\
\hline MD & $(60)$ & 36 & - & - & (3) & $<1$ \\
\hline MB, CM Edinburgh & - & - & (304) & 4.7 & - & - \\
\hline MB, CM Glasgow & - & - & - & - & (378) & 56 \\
\hline Medical corporation licence only & $(60)$ & 36 & $(164)$ & 25 & (150) & 22 \\
\hline \multicolumn{7}{|l|}{$\begin{array}{l}\text { Both a Univ. degree from the } \\
\text { same Univ. and a medical } \\
\text { corporation licence }\end{array}$} \\
\hline \multicolumn{7}{|l|}{$\begin{array}{l}\text { Both a Univ. degree from } \\
\text { another Univ. and a medical }\end{array}$} \\
\hline Degree from a another Univ. & - & - & (23) & 4 & (44) & 7 \\
\hline Total obtaining a qualification & $(165)$ & 100 & $(654)$ & 100 & (678) & 100 \\
\hline \multicolumn{2}{|c|}{$\%$ with a qualification } & 37 & & 64 & & 70 \\
\hline \multicolumn{2}{|c|}{$\begin{array}{l}\text { Total not obtaining a qualification (285) } \\
\text { (including some who died before } \\
1885)^{* *}\end{array}$} & & (371) & & (296) & \\
\hline \multicolumn{2}{|c|}{$\%$ without a qualification } & 63 & & 36 & & 30 \\
\hline \multirow{2}{*}{$\begin{array}{l}\text { Total students in the cohort } \\
\%\end{array}$} & $(450)$ & & $(1025)$ & & (974) & \\
\hline & & 100 & & 100 & & 100 \\
\hline \multicolumn{7}{|c|}{$\begin{array}{l}\text { *The qualifications refer only to first or primary qualifications. (The three MDs from Glasgow began } \\
\text { their medical studies before } 1 \text { October } 1861 \text { and obtained their degrees according to the regulations which } \\
\text { then applied when the MD was the primary qualification.) The figures for Edinburgh University in the } \\
1820 \text { s include only students who obtained an MD from Edinburgh and licences from the Royal College } \\
\text { of Surgeons of Edinburgh; this underestimates the total number of students who acquired a qualification. } \\
\text { Rosner suggests elsewhere in her book (p. 118) that "occasional auditors" had declined from } 80 \% \text { of the } \\
\text { students in } 1760 \text { to } 56 \% \text { of the students in the } 1820 \text { s, suggesting that } 44 \% \text { of the students in the } 1820 \text { s } \\
\text { acquired some type of certification. } \\
\text { **This category contains those who died as students. Also, as described in the text, it includes those } \\
\text { who died before } 1885 \text { who qualified by licence or a degree from another university (estimated at } 20 \text { for } \\
\text { Edinburgh and } 22 \text { for Glasgow). It does not include those who died before } 1885 \text { who qualified by means } \\
\text { of a degree at their own university (known to be } 43 \text { at Glasgow from Addison, op. cit., see note } 55 \text { below; } \\
\text { and estimated, based on the Glasgow figure, to be } 42 \text { at Edinburgh). } \\
\text { Sources: For Edinburgh in the } 1820 \text {, see Lisa Rosner, Medical education in the Age of Improvement, } \\
\text { Edinburgh University Press, } 1991 \text {, p. } 170 \text {; Edinburgh University c1871 and Glasgow University c1871 are } \\
\text { calculated from the Edinburgh University First Matriculation Forms (1869-73), University of Edinburgh } \\
\text { calendar (1869-73), the Glasgow University Matriculation Albums (1866-1874), University of Glasgow } \\
\text { calendar (1866-1885), the Medical Register (1885), the Medical Directory (1870-1920). }\end{array}$} \\
\hline
\end{tabular}


Total in cohort

Total qualifying

Total taking a degree from the same university
Edinburgh

1,025

654

455
Glasgow

974

678

462

A high proportion of each cohort never qualified, for reasons which will be explored, and around a third of those who did qualify had done so by other routes.

Further evidence of nomadic habits is available for different groups of matriculands. At first matriculation, for example, the University of Edinburgh collected information from medical students about their previous school, university and apprenticeship. ${ }^{35}$ Twentyseven per cent (277) of the Edinburgh matriculands had studied medicine before coming to the University, and the amount of time they spent can be seen in Table 2. This shows that 46 per cent of those students who had studied medicine before matriculating at Edinburgh, and for whom information is available, had spent two or more years at other institutions. This might imply that they had "shopped around" for their education, and was the kind of progress which worried the GMC.

\section{Table 2}

Time Spent Studying Medicine Prior to the First Matriculation at Edinburgh University, by those -Students with Previous Medical Education $(n=277)$

\begin{tabular}{lcc} 
Time & $\begin{array}{c}\text { Students with previous } \\
\text { medical education } \\
(\mathrm{n})\end{array}$ & $\begin{array}{c}\text { Those with Time } \\
\text { information available } \\
\%\end{array}$ \\
\hline$<$ yr & $(44)$ & 19 \\
lyr & $(82)$ & 35 \\
$2 \mathrm{yrs}$ & $(64)$ & 28 \\
3yrs & $(26)$ & 11 \\
4yrs & $(3)$ & 1 \\
5yrs & $(10)$ & 4 \\
6yrs & $(3)$ & 1 \\
7yrs & $(0)$ & 0 \\
8yrs & $(1)$ & 1 \\
Not available & $(44)$ & - \\
Total (n) & & $(233)$ \\
\hline
\end{tabular}

Source: Edinburgh University First Matriculation Forms (1869-73).

The Edinburgh records also indicate the previous place of study, and those who studied in London or Ireland are broken down in Table 3.

35 See University of Glasgow matriculation albums, 1866-74 (available in two volumes in the University of Glasgow Archives), and the University of Edinburgh first matriculation forms, 1869-73 (bound in yearly volumes, available in the University of Edinburgh Library Special Collections). 


\section{Table 3}

Place of Medical Study Prior to First Matriculation at Edinburgh University, for those Students with Previous Medical Education in London or Ireland

\begin{tabular}{|c|c|c|c|}
\hline Place & $\begin{array}{l}\text { All } \\
\text { Matriculands } \\
\text { (n) }\end{array}$ & $\begin{array}{l}\text { Did not } \\
\text { Qualify } \\
\text { (n) }\end{array}$ & $\begin{array}{l}\text { Qualified } \\
\text { (n) }\end{array}$ \\
\hline \multicolumn{4}{|l|}{ London } \\
\hline Charing Cross & 1 & & 1 \\
\hline College of Surgeons & 1 & & 1 \\
\hline Guy's & 10 & & 10 \\
\hline King's College & 9 & 2 & 7 \\
\hline London & 1 & & 1 \\
\hline London Hospital & 2 & 2 & \\
\hline Middlesex & 1 & & 1 \\
\hline St Bartholomew's & 7 & 2 & 5 \\
\hline St George's & 2 & 2 & \\
\hline St Mary's & 3 & & 3 \\
\hline St Thomas's & 3 & & 3 \\
\hline University College & 11 & 5 & 6 \\
\hline Total (n) & 51 & 13 & 38 \\
\hline \multicolumn{4}{|l|}{ Ireland } \\
\hline Belfast & 6 & 3 & 3 \\
\hline Dublin & 3 & 3 & \\
\hline New College, Dublin & 1 & & 1 \\
\hline Queen's College, Cork & 1 & & 1 \\
\hline Queen's College, Galway & 3 & 2 & 1 \\
\hline $\begin{array}{l}\text { Royal College of Surgeons } \\
\text { Ireland }\end{array}$ & 2 & & 2 \\
\hline Total (n) & 16 & 8 & 8 \\
\hline
\end{tabular}

Source: Edinburgh University First Matriculation Forms (1869-73).

From Table 3 it may also be seen that, if many students were attempting to escape the rigours of a London degree, then the proportion in Edinburgh was nevertheless small (less than 5 per cent of the whole cohort of 1,025 matriculands).The figures also indicate that several did not benefit by the move, since they stilled failed to qualify.

Edinburgh was meticulous in charting the mobility of candidates for examinations on the examination schedules of those who obtained a degree, an indication of how thoroughly it implemented the regulations of the GMC and the Ordinances of the Scottish Universities Commissioners. ${ }^{36}$ The Glasgow examination schedules record only the set of marks that each candidate received and there is no equivalent to the detailed records of

\footnotetext{
36 The final examination schedules for Glasgow are in the Glasgow University Archives, and those
}

for Edinburgh in Edinburgh University Library Special Collections, op. cit., note 24 above. 
Edinburgh. Nor did the Glasgow matriculation albums record any previous education; but there are indications that Glasgow students were also mobile. The average age of first matriculands at Glasgow was 21 compared to 20 at Edinburgh, ${ }^{37}$ suggesting a previous period of medical study or other employment. And, as mentioned above, the evidence submitted to the Select Committee of 1879 indicated that 12 per cent of those receiving degrees from Glasgow during the three years 1876-8 took at least one year of their training at another medical school, compared with 19 per cent at Edinburgh. ${ }^{38}$

Mobility is also seen in the time that students took to obtain their first registerable qualification. As the minimum period between registration and qualification was four years, cohort members who spent less time than this at the two universities must have attended at least one other medical school. At Glasgow only 17 per cent, and at Edinburgh 18 per cent of the students in the cohort who qualified came into this category, figures which closely match those reported to the Select Committee. This may have included the group of failures seeking an easy degree which caused such concern to the GMC, but, as has been seen, their numbers cannot have been large. It will also be argued that the Scottish university degree was no easy target.

Evidence for a diversified medical education is found in the qualifications obtained by cohort members. After 1858 nineteen institutions in Britain and Ireland offered a range of registerable qualifications. The Act established that any person with a single registerable primary qualification in medicine or surgery could practise anywhere in the United Kingdom. ${ }^{39}$ The period in which our cohorts obtained their qualifications was one of transition between the single qualifications in medicine or surgery before the 1858 Medical Act (general practitioners qualifying in England usually had two single qualifications, the LSA and LRCS) and the system of conjoint qualifications in both medicine and surgery available after 1886. In this, the Scottish universities and corporations were ahead of their English rivals.

The Commissioners appointed under the Universities (Scotland) Act 1858 created ordinances which transformed the MD into a higher degree and established the MB, CM as the joint qualification in both medicine and surgery. Before the Medical Act a degree in Medicine from any Scottish university entitled its holder to practise both medicine and surgery throughout Scotland, except where exclusive privileges in surgery were claimed by the RCSE and the Faculty of Physicians and Surgeons of Glasgow (FPSG). The degree conferred "the right to practise as a general practitioner". The Medical Act allowed qualified practitioners to practise in any part of the United Kingdom, eliminating the territorial jurisdiction of the medical corporations, but ironically doubt was raised whether the possession of a degree in Medicine from a university proved that its holder was also competent to practise surgery, even though the course of study for a medical degree at Edinburgh, Glasgow or Aberdeen included instruction in both medicine and surgery. Hence the "conditions of education and examination" which the Commissioners prescribed for the

\footnotetext{
37 Figures calculated from returns in the University of Glasgow matriculation albums, 1866-74 and University of Edinburgh first matriculation forms, 1869-73, op. cit., note 35 above.

38 Parliamentary Papers 1880 (121), p. 78, op. cit., note 12 above, Appendix No. 4.
}

39 Anyone could practise medicine but nonqualifiers did not enjoy the right to sue for fees or call themselves "doctor". Only registered practitioners could hold public posts such as Poor Law Union Medical Officer. 
degree of MB were intended to ensure the same amount of training in both medicine and surgery as formerly offered for the degree of MD. To demonstrate their competence in surgery for the purposes of the Medical Register, Scottish graduates could acquire a degree of Master of Surgery on payment of a fee of five guineas. ${ }^{40}$ There was nothing underhand in this, since the graduates had been fully trained in surgery, and most students in the $1860 \mathrm{~s}$ and 1870 s took both the MB and CM. ${ }^{41}$ The payment for the CM, in this complicated system, probably contributed to English misunderstanding of Scottish medical degrees: and the War Office, which was at first inclined to refuse to accept Scottish degrees as qualifications for military surgery, was set right by the GMC. It was also suggested that characteristic elements of thrift were visible in the system, since it saved Scottish graduates from taking two separate and expensive examinations in medicine and surgery.

One of the key responses to the 1858 Medical Act was the Scottish medical corporations' creation of a "double" qualification in medicine and surgery, examined and awarded by two conjoint boards: the two Royal Colleges of Physicians and Surgeons in Edinburgh; and the FPSG and the Royal College of Physicians (Edinburgh). ${ }^{42}$ No similar development took place in England until $1886,{ }^{43}$ so the Scottish system anticipated the British norm.

Although the majority of students in the cohorts who qualified were the stable majority in the university medical schools, Table 1 also indicates that a large minority obtained qualifications elsewhere. Approximately one-quarter at both universities (25 per cent at Edinburgh and 22 per cent at Glasgow) qualified by means of a licence from a medical corporation, in most cases the "double" qualifications of the conjoint boards of the Scottish medical corporations; while 6 per cent at Edinburgh and 10 per cent at Glasgow obtained a university degree from another university either on its own or with a licence from a medical corporation.

The students who qualified by these alternative routes made use of an open market in medical qualifications. There was also an asymmetrical traffic between Glasgow and Edinburgh. Forty-nine students in the Glasgow cohort subsequently qualified at Edinburgh, while only eleven of the Edinburgh cohort qualified at Glasgow, suggesting not only mobility but also the difference in prestige between the two institutions. Those obtaining only the licences or "double" from the medical corporations indicate the flexibility of the system, and its attraction as a cheaper alternative for poorer students in both cohorts.

\footnotetext{
40 Parliamentary Papers 1878 [C.1935], pp. 31-2, 'Report of the Royal Commissioners appointed to inquire into the universities of Scotland ..., vol. I.

41 Scottish Universities Commission, op. cit., note 27 above, pp. xxxii-iii, 221-31. For the case of the medical corporations against the Ordinances see also: Report of proceedings before a committee of Her Majesty's most honourable Privy Council ... relative to the ordinance of the Scottish Universities' Commissioners ... to regulate the granting of degrees in medicine and surgery in the University of Edinburgh, Edinburgh, T \& T Clark, 1861.

42 The object of the joint examination was thrift, i.e., "to give students facilities for obtaining from two separate bodies, and at less expense, a double
}

qualification in Medicine and in Surgery. Students, passing that examination successfully, will be enabled to register two qualifications under the Medical Act". Scottish Universities Commission, op. cit., note 27 above, p. 226.

43 This was not for want of trying. Several attempts were made to create a conjoint diploma between the Royal College of Surgeons England and the Royal College of Physicians London. The prospect of a single portal for qualification proved a disincentive to the formation of English conjoint boards, and it was not until the collapse of the singleportal scheme that conjoint boards were formed. See Newman, op. cit., note 8 above, pp. 132-3, 227-41, 298-9; Parry and Parry, op. cit., note 4 above, p. 130. 
For those who qualified at Edinburgh or Glasgow, Table 1 suggests a pattern of qualifications similar to Lisa Rosner's picture of Edinburgh in the 1820s. She demonstrates that by the 1820 s nearly all those attending lecture courses matriculated, and apprentices had nearly disappeared, while licentiates of the RCSE increased. The licence of the RCSE had become nearly equivalent to the University MD and was a popular alternative taken by about the same proportion of students ( 36 per cent) as the MD, while another group of students ( 27 per cent) took both. ${ }^{44}$ The main change between the $1820 \mathrm{~s}$ and 1870 s was an increase in the proportion of students obtaining a qualification (from 37 per cent in the 1820 s to at least 64 per cent at Edinburgh and 70 per cent at Glasgow in the 1870s) and a continuation of the decline in the group Rosner describes as "occasional auditors" who matriculated and attended some courses but did not gain a medical qualification. She points out that the proportion of auditors among the Edinburgh students declined dramatically between 1760 and the 1820 s and ascribes it to "the increase in demand and opportunities for formal certification" ${ }^{45}$ Nevertheless, Table 1 indicates that there were still considerable numbers of matriculands (36 per cent at Edinburgh and 30 per cent at Glasgow) who did not appear in the Medical Register by $1885 .^{46}$ The reasons for this relatively high number of non-qualifiers need to be examined, both because the non-qualifiers contradict the contemporary notion that Scottish degrees were easy to obtain, and because student transfers between institutions encouraged this contemporary prejudice.

\section{Completion and Non-completion}

Historians have only cursorily explored the completion rates of medical students in the mid-nineteenth century. ${ }^{47}$ The evidence usually cited is the nineteenth-century research of Sir James Paget and S Squire Sprigge, both of whom were concerned more with the status of medical practitioners in Victorian society than with mechanisms for the control of professional supply. ${ }^{48}$ In his essay, 'What becomes of medical students' published in 1869, Paget traced the careers of 1,000 of his former pupils up to fifteen years after entering the medical school at St Bartholomew's Hospital between 1839 and $1859 .{ }^{49}$ It is difficult to compare Paget's results directly with the information obtained from later university records, since his students did not require a medical qualification in order to practise, but some attempt can be made. His figures for those who had dropped out of the profession up to fifteen years after entering St Bartholomew's include the following categories:

\footnotetext{
44 Rosner, op. cit., note 8 above, pp. 170-1, 203. Similar to Rosner's 27 per cent, Table 1 indicates that in 187125 per cent of the Edinburgh cohort who qualified and 15 per cent of the Glasgow cohort took both a university degree from their own or another university, and a licence from a medical corporation.

45 Ibid., ch. 6, esp. p. 118.

46 Their names do not appear in the Medical Register or any section of the Medical Directory.

47 W F Bynum, 'Medical values in a commercial age', in T C Smout (ed.), Victorian values, Oxford
}

\author{
University Press, 1992, pp. 153-5; M Jeanne \\ Peterson, 'Gentlemen and medical men: the problem \\ of professional recruitment', Bull. Hist. Med., 1984, \\ 58: 457-73. \\ 48 Stephen Paget (ed.), Memoirs and letters of Sir \\ James Paget, London, Longmans, Green, 1902, \\ pp. 244-5; S Squire Sprigge, Medicine and the \\ public, London, Heinemann, 1905, pp. 33-7. \\ 49 James Paget, 'What becomes of medical \\ students', Saint Bartholomew's Hospital Reports, \\ 1869, 5: 238-42.
}




\section{James Bradley, Anne Crowther, Marguerite Dupree}

96 discontinued their medical studies or abandoned practice

41 died during pupillage

56 had "failed entirely" in the profession

(including 15 who could not pass their examinations)

87 died within 12 years of beginning practice.

This would give a rate of disappearance of some 27 per cent within 15 years of beginning study, though Paget's figures are not very clear in distinguishing between those who discontinued their medical studies, and those who left after beginning practice. Only 37 are clearly listed as abandoning their studies: the other figures are indeterminate. ${ }^{50}$ Squire Sprigge describes the 96 escapees as students who "discontinued their medical studies while in pupilage", but Paget's article is ambiguous. 51

Squire Sprigge repeated Paget's exercise, and published his results in 1905. He examined the careers of the first 250 students entering St George's Hospital Medical School after 1 October $1879 .{ }^{52}$ Sprigge did not indicate those who failed examinations in his study, but 63 (25 per cent) of his students did not qualify, and he argued that, unlike in Paget's day, the "multiplicity of examinations" was likely to be an important factor. ${ }^{53} \mathrm{~A}$ roughly comparable table to Paget's could be constructed:

61 failed to qualify

2 died during pupillage

23 died with in 12 years of qualification

$11 \mathrm{failed} / \mathrm{left}$ profession after qualification.

This brings Sprigge's figures for those not practising within 15 years of beginning study to 39 per cent, though his death-rate during pupilage is considerably lower than Paget's. This low death-rate during pupilage may be an accident of unsatisfactory statistics, but it may also reflect the declining adult death rate among young adults between the two studies. ${ }^{54}$ Both Paget and Squire Sprigge mention intellectual incapacity and frivolous behaviour (as well as poor health) as reasons for failing in medical study or after beginning practice.

Although the reasons for failing to qualify cannot be disaggregated with total precision in the Edinburgh and Glasgow cohorts, information about them may be combined with a study by the GMC to provide a comparison. Discovering the qualifications of cohort members was a two-step process. Matriculands were linked to lists of graduates in the Calendars of Edinburgh and Glasgow Universities. The cohorts were then linked to the Medical Register (1885) to identify those obtaining diplomas or licences from medical corporations and degrees from other universities. Those with diplomas or degrees who emigrated still appeared in the Medical Register (and in a section of the Medical Directory for 'Practitioners Resident Abroad'); but, inevitably, some cohort members qualifying outside the two universities were not in the Medical Register because they had died or left

50 Ibid., pp. 240-1.

51 Sprigge, op. cit., note 48 above, p. 31.

52 Sprigge's sample would obviously not stand up to modern statistical methodology, whereas Paget's work, including nearly all of his students with information available, is more satisfactory.

\footnotetext{
53 Sprigge, op. cit., note 48 above, p. 32.

54 Ibid., p. 34. Robert Woods, The population of Britain in the nineteenth century, Basingstoke and London, Macmillan, 1992, p. 57. Paget particularly noticed the incidence of phthisis in 17 of his students.
} 
the profession in the interval between qualification and 1885. Not all deaths could be identified, unlike the precise personal knowledge of Squire Sprigge and Paget, but it is known that at least 43 Glasgow graduates in medicine were dead by 1885.55 Unfortunately, it is not possible to quantify practitioners dead before 1885 who had taken a degree or licence elsewhere, nor those dying during pupilage, but if we assume the same ratio of deaths for licentiates as for graduates, and add a conjectural death-rate for pupils based on Squire Sprigge's figures ( 0.8 per cent), then an estimated 22 members of the Glasgow cohort who qualified by licence or a degree from another university and 20 of the Edinburgh cohort in a similar position would have been dead by 1885.56

To summarize: 36 per cent (or 372) of students who matriculated in medicine at Edinburgh and 30 per cent (or 296) at Glasgow had failed to gain a medical qualification, or had died, by 1885 . The GMC compiled similar figures for all medical students on their list of new students in Scotland for 1871 . They discovered that 30 per cent of this group had not registered a qualification by 1885.57 The difference between Glasgow and Edinburgh requires some explanation. Edinburgh attracted more students from overseas than did Glasgow. Some of these might not have intended to qualify in Britain and so not registered with the GMC. Women students at Edinburgh also affect the completion rate, for the Edinburgh cohort includes the early women pioneers, including Sophia Jex-Blake. Thirty-nine women matriculated for the first time to study medical subjects at Edinburgh between 1869 and 1873, including those who matriculated to study "physiology", but only eight qualified. It is known that a few of the serious candidates (to Miss Jex-Blake's disappointment) were distracted from qualifying by marriage or family responsibilities, ${ }^{58}$ but most seem to have been "auditors" of a particular kind. They had signed up for medical or physiological classes via the Edinburgh Ladies Education Association (ELEA), not because they intended a serious study of medicine, but through interest or a strong sense of feminist solidarity with Jex-Blake and her companions, despite Jex-Blake's own ambivalent relationship with the ELEA. ${ }^{59}$ In 1871,22 women matriculated, but only two were listed on the GMC student register of that year to indicate an intention of qualifying.

\footnotetext{
55 Information from William Innes Addison, Roll of the graduates of the University of Glasgow 1727-1897, Glasgow, J Maclehose, 1898.

56 The estimated figures for deaths among those who qualified, based on fairly solid evidence for Glasgow, are comparable to those of both Paget and Sprigge, and are more reliable than the estimate for deaths among the student body. We use Sprigge's low figure for deaths during pupilage as more contemporary than Paget's, and reflecting the mortality decline in this age group since Paget. See Woods, op. cit., note 54 above, p. 57.

57 Report by the Statistical Committee of the General Medical Council, op. cit., note 16 above, p. 10. The groups are slightly different. Those in the GMC's List of medical students are those who began their medical studies in 1871, while the cohorts of first matriculands include some who had begun their medical studies elsewhere.
}

\author{
58 Margaret Todd, The life of Sophia Jex-Blake, \\ London, Macmillan, 1918, pp. 340-1; Shirley \\ Roberts, Sophia Jex-Blake: a woman pioneer in \\ nineteenth-century medical reform, London, \\ Routledge, 1993, p. 118. \\ 59 For an informative account of the ELEA and \\ medical women at Edinburgh see: Sheila Hamilton, \\ 'Women at Scottish universities 1869-1939: a social \\ history', PhD thesis, Edinburgh University, 1988, chs \\ 1 and 2 . See also Todd, op. cit., note 58 above, pp. \\ 252, 260-1, 323; and Roberts, op. cit., note 58 \\ above, pp. 90, 112, 118. For a brief account, Carol \\ Dyhouse, No distinction of sex? Women in British \\ universities 1870-1939, London, UCL Press, 1995, \\ p. 15. This was part of a long tradition of women's \\ interest in science in Britain, see Patricia Phillips, \\ The scientific lady: a social history of women's \\ scientific interests 1520-1918, London, Weidenfeld \\ and Nicolson, 1990, pp. ix-xiii, 213-23, 251-7.
}




\section{James Bradley, Anne Crowther, Marguerite Dupree}

Nevertheless, once deaths and women are discounted, it is still necessary to explain why approximately 30 per cent (or 312) of students who matriculated in Edinburgh, and 27 per cent (or 266) at Glasgow, did not qualify. There are three possible explanations. Some students may never have intended to qualify: instead, they were dropping into medical education for interest or to acquire skills for other careers. Others may have been prevented from completing their education due to ill-health or poverty. Finally, failure in professional examinations must also be considered.

Of those who never intended to qualify, some may have seen a little tuition in medicine as a useful supplementary training for the ministry or mission fields. Others may have been studying science, which, before the foundation of science faculties, required attendance at lectures in both the medical and arts faculties. ${ }^{60}$ This group would therefore show some similarities with Rosner's "occasional auditors" earlier in the century. These possibilities can be explored by analysing the Glasgow matriculation albums, which give a student's branch of study. ${ }^{61}$ Because the students matriculated at the beginning of each year, the information about an individual can be linked from year to year to reveal how long a student was attached to a particular branch. The hypothesis that some students never intended qualifying can be tested by looking at their movements between branches of study. Students often matriculated in branches consisting of more than one faculty: a typical example of this is matriculation in "Medicine and Arts". Some indicated a branch which spanned faculties, like "Science". To add to the confusion, students combining "Medicine and Arts" could have been chiefly interested in scientific subjects, rather than medicine.

However, the largest group of those who failed to qualify belonged to the group who matriculated in medicine only, as the following figures show:

Total not on Register in 1885

of whom

Those matriculating in medicine only

Those combining medicine with another subject, or subjects

This suggests that medicine was the main interest of most of those who had matriculated but failed to qualify by 1885 . Of the 98 who studied medicine with another subject, 35 pursued it for more than two years, suggesting more than a passing interest. Only 26 students seemed to be using medicine to supplement another vocational subject such as Divinity.

The matriculation albums provide further indication of the movements of medical students who did not qualify, as it is possible to see how long each of the matriculands studied medicine at the University of Glasgow (Table 4).

Of the 198 students who matriculated in medicine only, 108 disappeared from the University at the end of their first year. Some who had begun their medical studies elsewhere could take their first professional examination at the end of their first year rather than at the end of the second year of study (as required of those who had begun their studies at Glasgow) and examination failure might account for their disappearance. Some students may have intended to practise medicine, but found after a year or more of study that they were unsuited to it.

60 Robert Y Thomson (ed.), A faculty for science: a unified diversity, Glasgow, The University, 1993.

61 Unfortunately it is not possible to make comparisons with Edinburgh because the surviving sources do not allow the tracing of Edinburgh students through their education. 
Table 4

Glasgow University Students who Matriculated in Medicine Only, but did Not Qualify: Number of Years Studied

\begin{tabular}{lrr} 
(n) & Students & $\%$ \\
\hline Years & $(108)$ & 55 \\
2yrs & $(23)$ & 12 \\
3yrs & $(18)$ & 9 \\
4yrs & $(30)$ & 15 \\
5yrs & $(12)$ & 6 \\
6yrs & $(6)$ & 3 \\
7yrs & $(1)$ & $<1$ \\
Total & $(198)$ & 100
\end{tabular}

Sources: Glasgow University Matriculation Albums (1866-74); machine-readable dataset of the Glasgow University Matriculation Albums (1859-1888) available in the Glasgow University Archives; University of Glasgow calendar (1866-1885); the Medical Register (1885), the Medical Directory (1885).

Physical or financial problems may also have prevented completion. It is not possible to estimate the proportion of students who quit due to ill-health; but financial difficulties were a more likely cause for non-completion, particularly if the student came from a poor background. Unless he won a bursary or scholarship, all expenses had to be met from personal or family incomes. Analysis of the social background of the Glasgow cohort, based upon father's occupation, reveals that while as many as 18 per cent came from families associated with the old professions, the majority came from middle- or lowermiddle-class backgrounds. ${ }^{62}$ Many would have been similar to Arthur Conan Doyle during his days at Edinburgh. Living and studying at his home in the city, he had to scrimp to help his mother pay for his medical education. ${ }^{63}$

The system could accommodate the financially struggling student alongside the wealthy sons of professionals because of the variation in the cost of medical education. Edinburgh University provided a detailed breakdown of costs, estimating that if each course of lectures was taken only once, and the recommended curriculum followed, the expense would be $£ 104.18$ s. $^{64}$ Glasgow gave no comparable figures, but where Edinburgh University lecture courses cost around three or four guineas, depending on length, most courses at Glasgow cost only three. Hospital attendance at the Glasgow Royal Infirmary or, after 1874, the Western Infirmary, was cheaper than the Edinburgh Royal Infirmary at 10 guineas. ${ }^{65}$ The minimum cost for the recommended Glasgow curriculum must have been at least $£ 90$.

\footnotetext{
62 Further details on social background are given in Anne Crowther and Marguerite Dupree, 'The invisible GP: the careers of Scottish medical students in the late nineteenth century', Bull. Hist. Med., (forthcoming).

63 Arthur Conan Doyle, Memories and adventures, London, Greenhill Books, 1988; first published London, Hodder and Stoughton, 1924.

64 Edinburgh University calendar 1875-76, op.
}

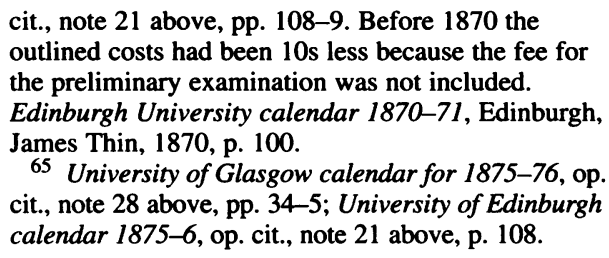
outlined costs had been 10 s less because the fee for the preliminary examination was not included.

Edinburgh University calendar 1870-71, Edinburgh, James Thin, 1870, p. 100.

65 University of Glasgow calendar for 1875-76, op. cit., note 28 above, pp. 34-5; University of Edinburgh calendar 1875-6, op. cit., note 21 above, p. 108. 


\section{James Bradley, Anne Crowther, Marguerite Dupree}

The idea of students taking each course of lectures only once was unrealistic. The examination schedules suggest that many took courses two or more times, or attended more courses than required. For example, James Altham, who matriculated at Edinburgh in the summer of 1875 took extra courses in Botany, Anatomy, Practical Anatomy, Clinical Surgery, and Clinical Medicine. There was no apparent need for this; Altham passed all his professional examinations with ease and graduated with distinction in 1880 . Rather, he chose to take an extra year to consolidate his education. Altham's progress to qualification was quite common. Students at Edinburgh often took two courses of-lectures in Anatomy: one at the beginning of their medical studies and the other near the second professional examination. A great deal of importance was also given to Practical Anatomy. Many chose to do twice as much as was required by the ordinances. ${ }^{66}$ Repeated attendance at a lecture course may have resulted from lack of confidence before the professional examination but, whatever the reason, it would increase the duration, and the cost, of a medical education. ${ }^{67}$

Edinburgh and Glasgow were in the mid-range of fees, and some of the London hospitals were considerably more expensive. St Bartholomew's charged $£ 135.5 \mathrm{~s}$ and St Thomas's $£ 125$ for two years, while the Middlesex was relatively cheap at $£ 94.10$ s for three years. Bristol and Liverpool charged $£ 63$ for two sessions. ${ }^{68}$ In Scotland the extramural Edinburgh Medical School charged $£ 90.4 \mathrm{~s}$ for a complete course of medical education inclusive of examinations leading to the "double" qualification, ${ }^{69}$ while in Glasgow, Anderson's College offered many of the courses necessary to complete a medical degree for two guineas. ${ }^{70}$ In both England and Scotland it was possible to buy a cut-price education, thus raising the kind of objections found in the evidence to the Select Committee. As Keetley commented in his Guide, eyeing all-important status considerations, "some provincial medical schools are only cheap in the sense which inferior articles are cheap", ${ }^{71}$ adding "two persons out of three who have been educated wholly at a provincial school regret it". His list of superior medical schools included Edinburgh, but not Glasgow. ${ }^{72}$

In addition to fees, a student would have to buy books and dissecting equipment, and meet normal living expenses. Keetley reckoned that students needed a minimum of eight books, and recommended an array of medical equipment including a microscope at a cost of 5 guineas. ${ }^{73}$ In all, he estimated that books and equipment cost approximately $£ 15 .{ }^{74}$ The cost of living would vary according to class and region. Keetley believed that board and lodging in London ranged from 25s a week for poor students to a norm of 37s a week. As the medical year lasted 9 months, this worked out at between $£ 50$ and $£ 74$ per year. Costs in Edinburgh and Glasgow were lower, but still a consideration, although about 11

66 'Final examination schedules of the University of Edinburgh 1880', op. cit., note 24 above.

67 If students repeated their attendance at certain courses of lectures at Edinburgh in the mid-1870s, they paid a reduced fee. Thus, the second course of lectures in Anatomy cost 3 guineas, and the third was free. Edinburgh University calendar 1875-76, op. cit., note 21 above, p. 94 .

68 Figures provided in Charles Bell Keetley, The student's and junior practitioner's guide to the medical profession, 2nd ed., London, Baillière,
Tindall, and Cox, 1885, pp. 116-17. The figures were taken from the British Medical Journal, Sept. 8, 1883.

69 University of Edinburgh calendar 1875-76, op. cit., note 21 above, Advertisment Section (no page numbers given).

70 University of Glasgow calendar for 1875-76, op. cit., note 28 above, p. 17.

71 Keetley, op. cit., note 68 above, p. 13.

72 Ibid., p. 24.

73 Ibid., pp. 28-33.

74 Ibid., p. 15. 
per cent of Edinburgh students and 47 per cent of Glasgow students were probably living at home. ${ }^{75}$ While this was an advantage for families with limited means, the support of a young adult not engaged in paid employment would drain household resources.

At both Edinburgh and Glasgow there were a number of scholarships and bursaries which, for the fortunate few, might have offset some of the expense. At Edinburgh, for example, in 1875-6 there were four different bursary funds (giving 12 separate awards), one scholarship and a number of prizes. None was worth more than $£ 30$ per annum. ${ }^{76}$ Medicine in Glasgow was less well endowed than other faculties, and even by 1878, after new endowments, there were only fifteen medical bursaries worth $£ 425$ in all. ${ }^{77}$

Keetley estimated that the total cost of a London medical education was about $£ 600 .^{78}$ Peterson has argued that this estimate was a maximum, and calculated that with cheap lodgings and limited pocket money, it would be possible to complete a medical education for between $£ 331$ and $£ 411$ (or $£ 183$ to $£ 223$ in the provinces) in the years around $1884 .{ }^{79}$ All these calculations are based on the assumption that a student would complete his degree in the minimum time possible, but most students were taking longer. Fifty-three per cent of students in England and 56 per cent in Scotland who were listed in the GMC register of students beginning their medical studies in 1871 , and who subsequently qualified, took more than four years to do so. ${ }^{80}$ It is difficult to estimate the average cost of medical education in Scotland, which may have exceeded $£ 300$, with students from the colonies spending far more.

Any set-back in the parental finances might prevent the completion of medical studies. This was the experience of James Bridie's father, who went to Glasgow in the early 1880 s.

Before he settled into his chosen walk of life, he was a clerk in a business firm, supercargo on a windjammer sailing round the world and a medical student. When I use the word "chosen" I use it in the Calvinistic sense. If my father had had any personal choice in the matter he would have been a Doctor of Medicine. He was only allowed to follow this ambition for two years ... A financial storm drove him out of his course in 1882 and he began to be an engineer. ${ }^{81}$

The final explanation for the large number of non-qualifiers lies in the rate of failure in professional examinations, not only in the final examinations but particularly in the first, and for universities, the second professional examinations. (The medical corporations did not have second professional examinations.) The failure rates are revealed in figures provided to the GMC and published in 1880 in the 'Special Report of the Select Committee on the Medical Act' ${ }^{82}$

\footnotetext{
75 This is based on home birthplace given in the matriculation albums; a substantial group may also have commuted from nearby areas.

76 The Sibbald Scholarship was worth $£ 40$, but it was awarded only once every four years. A listing of the bursaries was printed in tabular form in each university calendar along with the conditions of award. See, for example, University of Edinburgh calendar 1875-76, op. cit., note 21 above, p. 312.

77 In Glasgow, thirteen bursary awards were available in 1875-6, some tenable in another faculties, with a range of values from $£ 12$ to $£ 50$ per annum. George H B MacLeod, Address delivered at the opening of the medical classes in the University of Glasgow on Monday, October 27, 1873, Glasgow,
}

James Maclehose, 1873, pp. 4-5; John G McKendrick, Address to the medical students at the opening of the winter session, University of Glasgow, Tuesday,

October 29, 1878, James Maclehose, 1878, p. 42.

78 Keetley, op. cit., note 68 above, p. 15.

79 Peterson, op. cit., note 5 above, p. 74.

80 Report of the Statistical Committee of the General Medical Council, op. cit., note 16 above, pp. $30-1$.

81 James Bridie, One way of living, London, Constable and Co., 1939, pp. 13-14. James Bridie was the pseudonym of Dr Osborne Henry Mavor.

82 Parliamentary Papers 1879 (320), p. 422, op. cit., note 2 above, Appendix No. 11, Paper 13; and p. 419, Appendix No. 11, Paper 12, Table IX. 


\section{James Bradley, Anne Crowther, Marguerite Dupree}

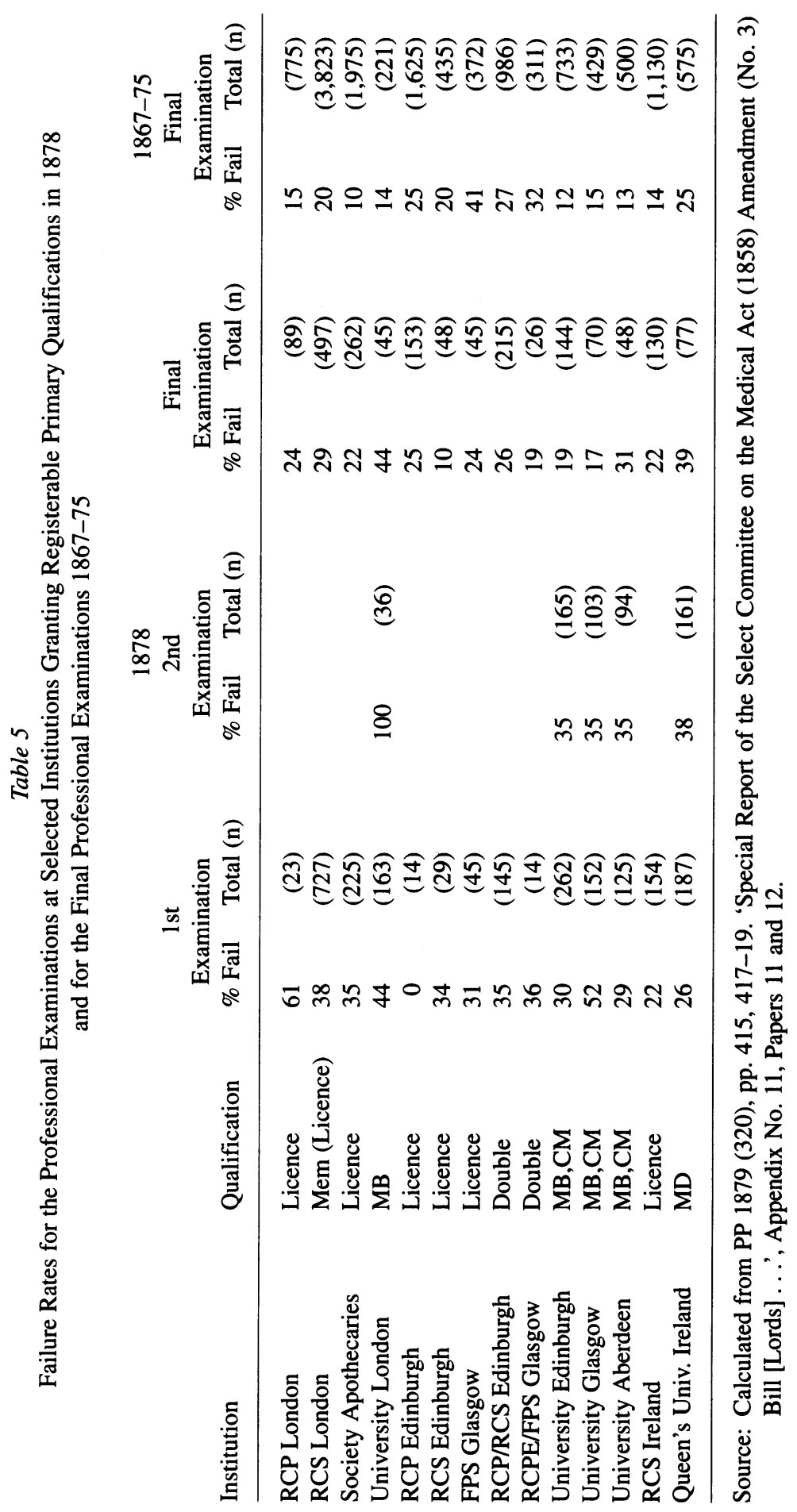


Table 5 indicates that in the first professional examination in 1878 nine of fourteen selected primary qualifications had failure rates of between 38 per cent and 26 per cent, or about one in three. Of the rest, the exceptionally high percentage of failures for the Licence of the Royal College of Physicians of London and the exceptionally low percentage of failures for the Licence of the RCPE are based on small numbers. The percentage failing at Glasgow University ( 52 per cent) is higher than that for the notoriously difficult University of London MB (44 per cent), ${ }^{83}$ while the percentage failing at the Royal College of Surgeons of Ireland (22 per cent) is only marginally lower than the main group. The relationship between the first and the final examinations is to some extent conjectural, since high pass rates in the latter may have been the result of severe culling in the former.

The failure rates for the final examinations in the several institutions in 1878 range widely. Yet, when the numbers failing the final examinations between 1867 and 1875 are averaged, the differences among universities are small. Edinburgh averaged a 12 per cent failure rate in the years 1867-75 compared with 13 per cent at Aberdeen, 14 per cent at London, and 15 per cent at Glasgow. The medical corporations tended to be higher. It has been shown that around a quarter of the matriculands who finally qualified, did so solely through the medical corporations in Edinburgh and Glasgow, but the failure rates for the "licence" or "double" do not indicate that these routes were easier to follow than a university degree. Hence the local universities were not necessarily processing students for an "easy" qualification via the colleges. This is not to deny the possibility that the examination standards at the different institutions varied widely: comments such as Keetley's suggest that this is so, and that students may have aimed at the institutions where they were most likely to succeed. But, despite the variations, the substantial proportions of failures at each stage of the examinations represent a further hurdle, a longer course, more expense and a potential contribution to the attrition rate.

Further evidence for the extent of failures can be found in the Edinburgh University examination schedules, which recorded the performance of candidates in each of the professional examinations. The 1880 schedules reveal a sorry pattern of failure before the eventual qualification. Most students failed a single course and-were remitted to the studies for three months before retaking the examination. Others failed more drastically and were forced to resit a year later: one student's career may be used here as an example. Thomas Gray matriculated in Medicine for the Winter Session of 1871. He took his first professional examination in April 1873 and failed all papers. He took it again in April 1874 and recorded a "bare pass". He took his second professional examination in July 1875 and was remitted to his studies in two subjects only: Physiology and Materia Medica. He managed to pass these in April 1876 but was admonished in Materia Medica for not attending the written paper which he had passed at the first attempt. He then failed his finals for the first time in June 1877. Two years later in June 1879 he failed them again. Finally, a year later he secured the elusive pass: unfortunately. he disappears from the Medical Directory after 1885 . Gray may not have been the best medical student, but he

${ }^{83}$ A L Mansell, 'Examinations and medical education: the preliminary sciences in the examinations of London University and the English Conjoint Board, 1861-1911', in R MacLeod (ed.),
Days of judgement: science, examinations and the organization of knowledge in late Victorian England, Driffield, N. Humberside, Nafferton Books, 1982, pp. 91-9, 104. 


\section{James Bradley, Anne Crowther, Marguerite Dupree}

was at least persistent. His path to qualification would have required mental, physical and financial stamina. His case does, however, raise the possibility that others had none of these qualities, resulting in failed examinations, disillusion and the search for another career. Perhaps the tolerance of James Bridie's father towards his son's dilatory progress in medical education stemmed from his own disappointment.

Much of the evidence points to a high rate of failure, and in response to a questionnaire from the GMC asking in "what subject or subjects are the rejections most frequent, and to what circumstances are these proportionately frequent failures of candidates attributable?", 84 Edinburgh University replied:

The rejections are most numerous in the subjects of the first examination for the degree of bachelor of medicine. At this examination the inferior men are weeded out, so that only the more competent candidates pass on to the later stages of the examinations. In the later stages the candidates are older, their minds are more matured and disciplined by study, and the proportion of rejections is consequently smaller. ${ }^{85}$

Contemporary debates tended, however, to cloud the historical reality of high failure rates and to fix the idea of an "easy" Scottish qualification. The existence of a mobile set of students had a serious impact upon perceptions of Scottish medical education. For most of this period a debate raged over the merits of the Scottish university "double" compared to the qualifications offered by the corporations. An illustration of this is seen in the comment made to a medical practitioner in 1865 "that few if any [Scottish] candidates failed at the second [qualifying] examination, which circumstance may account for the fact that so many men run off to Edinburgh or St Andrews to secure for themselves a university degree, where the examination ordeal is not nearly so severe as it is further south". ${ }^{86}$ Historically, the linking of Edinburgh and St Andrews was unfair, but it demonstrates that the extinct system of granting degrees by payment at St Andrews and the Aberdeen Colleges was still alive in the collective memory of the profession. Mobility between institutions also encouraged suspicious comments about standards of education and examination, and debates over establishing a single portal only exacerbated this situation. A primary argument of those campaigning for the unified system of qualification was the fear that Scottish universities were undercutting other institutions by offering easy degrees. Furthermore, it was often thought that any system which allowed teachers to examine their own students was inherently corrupt. ${ }^{87}$

Edinburgh University was particularly keen to impress upon its graduates the fallacious nature of these accusations. Professor Douglas MacLagan took the opportunity afforded him by the Graduation Address of August 1872 to deal with the accusations levelled at the University by Robert Lowe, quoted at the beginning of the article. Lowe had suggested that the Scottish Universities' system of teachers examining their own students was highly dubious, as it encouraged leniency in the examiners which devalued the Scottish

\footnotetext{
84 Parliamentary Papers 1879 (320), p. 366, op. cit., note 2 above, Appendix No. 11, Paper 3.

85 Ibid., p. 374, Appendix No. 11, Paper 3.

86 Quoted in Newman, op. cit., note 8 above, p. 229.

87 This criticism overlooks the fact that the Scottish Universities' Commissioners were aware of this potential allegation and they stipulated that the
}

\author{
Universities each appoint three external examiners in \\ addition to the Professors and that provision be made \\ from public funds to pay them substantial sums \\ ( $£ 100$ for each examiner at Edinburgh, $£ 80$ at \\ Glasgow, and $£ 60$ at Aberdeen). Scottish Universities \\ Commission, op. cit., note 27 above, p. xxxiii.
}


degrees. ${ }^{88}$ MacLagan recounted how Lyon Playfair, MP for the University of Edinburgh, had replied to these accusations, particularly alluding to the fact (partially confirmed by our own data) that from 1838 to 1870 only four medical graduates at London had been educated entirely at Edinburgh. MacLagan himself asked

as regards the inconceivable leniency in examination, I venture to appeal from $\mathrm{Mr}$ Lowe's assertion to your experience, and ask you, now that you have passed your examinations, whether this inconceivable leniency - whether, in short, on looking back at the trouble you have taken to prepare for your trials, you think that it was an unnecessary expenditure of labour? ${ }^{89}$

Since there were only five Scottish representatives among the twenty-four members of the GMC in the 1870s, it was difficult to prevent uninformed criticism within the professional bodies. Part of the background to an 1882 GMC visitation to examination bodies was the allegation that the regulations of the Scottish Universities, by allowing students to take their examinations for a medical degree after only one year of study, had led to an influx of failed students from other areas of Britain. This allegation revealed a misunderstanding of the Scottish university regulations, ${ }^{90}$ and neither the GMC nor the previous investigation by the Select Committee was able to find any confirmation of these accusations. ${ }^{91}$

\section{Conclusion}

Given the contemporary English assumptions, and the small number of examination failures mentioned by Paget, the high rates of failure throughout the country after 1858 have not featured in histories of medical education. Yet the evidence is that there was a deliberate attempt to rid the system of less able students, adding to the already substantial difficulties in gaining a medical qualification. In a system of education where entry was not regulated by academic ability, mechanisms were necessary to ensure a reasonable standard of professional qualification. Financial and other pressures, combined with high failure rates were key factors in regulating the supply of medical practitioners.

The diverse systems of medical education in the later nineteenth century allowed a relatively free market to the medical student, though the profession itself ranked the different schools in terms of prestige, based on "ease" of qualification. Mobility was still possible, and substantial numbers still obtained a qualification from one of the medical corporations. The free market, and student mobility, reinforced older professional stereotypes about "cut price" degrees, although contemporary evidence suggests that most medical qualifications were not gained either quickly or cheaply. Compared with Rosner's description of the eighteenth-century Scottish medical lecture audience, the students in the early 1870s appear relatively motivated. The "occasional auditors" had virtually disappeared, and most students seem to have intended a medical career. The failure of a substantial proportion to do so reveals a tightening of the profession's grip over its entrants. Until entry to medical education was controlled by a more selective system than

88 MacLagan, 'Address to the Edinburgh medical graduates', op. cit., note 1 above, p. 319.

89 Ibid., p. 320.

90 See p. 6 above and note 30.
91 The report of the Visitors of the General Medical Council, London, GMC, 1882. Parliamentary Papers 1879 (320), p. 384, op. cit., note 2 above. 


\section{James Bradley, Anne Crowther, Marguerite Dupree}

the gentlemanly preliminary examinations, this would remain the case. Professional examination was one of the main means to control the quality of supply, and in this even the large and apparently easy-going Scottish universities colluded. Appropriately in the years after the Origin of species, medical education operated on the principle of the survival of the fittest. 